\title{
The land use changes and its relationship with topographic factors in the Jing river catchment on the Loess Plateau of China
}

\author{
Zhi Li ${ }^{1 *}$, WenZhao Liư ${ }^{2}$ FenLi Zheng ${ }^{2}$ \\ From 2010 International Conference on Combating Land Degradation in Agricultural Areas (ICCLD'10) \\ Zi'An City, PR China. 11-15 October 2010
}

\begin{abstract}
A series of soil conservation measures have been carried out to reduce soil loss on the Loess Plateau of China since 1950s, and the biologic measures were implemented according to topographic factors such as slope and elevation; therefore, the changes in topographic factors of land use can indicate the effects of the biologic measures. The objectives of this study were to (i) analyze the land use changes in the Jing River catchment during 1986-2000 and to (ii) examine the effects of biologic measures through relating land use changes with topographic factors. During 1986-2000, the dominant land use types were farmland and grassland (88\% of the whole catchment). Compared with 1986, farmland and forest decreased while grassland and construction land increased with little changes in water and unused land. Three main conversion types occurred, i.e. the mutual conversion between forest and grassland, the mutual conversion between farmland and grassland, and farmland converted to other types. The elevation of farmland, forest, construction land and water increased, while that of grassland and unused land decreased. The mean slope gradient of each land use type changed little except for unused land. The above results suggested farmland has greatly decreased on tableland region due to the increase in construction land, forest has moved to gully region while grassland has increased despite elevation and slope. The land use in the Jing River catchment during 1986-2000 was changing to a more reasonable spatial pattern.
\end{abstract}

\section{Introduction}

The Loess Plateau $\left(6.4 \times 10^{5} \mathrm{~km}^{2}\right)$ is situated in north China. It is covered with highly erodible aeolian deposits. Most areas belong to semiarid to sub-humid climate with most precipitation falling in summer months largely in forms of heavy storms. Canopy cover degree is generally low, and land use is predominantly cultivated cropland and improved grassland. The Yellow River, which has highest sediment concentration in the world [1], runs through the Loess Plateau. Due to the above situation, the Loess Plateau has become one of the most severely eroded areas in the world [2,3].

Since 1950s, a series of conservation measures including replanting trees and improving grassland,

\footnotetext{
* Correspondence: lizhibox@126.com

'College of Natural Resources and Environment, Northwest A \& F University, Yangling Shaanxi, 712100 China

Full list of author information is available at the end of the article
}

constructing of terraces and sediment-trapping dams were implemented. Among these measures, returning steep farmland to forest and grassland was carried out in most areas to improve the vegetation over. Steep farmland accounts for about $50 \%$ of total farmland area on the Loess Plateau, and this situation is worse in the hilly-gully area, where steep farmland covers 70\%-90\% of the total farmland area and farmland with slopes over $25^{\circ}$ accounts for $15 \%-20 \%$ of the total farmland area [4]. Thus, vegetation construction would not only change the spatial distribution of land use, but also alter the slope of each land use type $[5,6]$. For example, $25^{\circ}$ was usually taken as the critical slope gradient of returning farmland to forest and grassland, which might decrease the slope of farmland and increase that of forest and grassland.

With the implementation of conservation measures, human choices of land use have also changed greatly

\section{SpringerOpen $^{\circ}$}


due to the impacts of elevation $[5,6]$. For example, farmland abandonment often occurred on the highest or lowest and the steepest areas while construction land often moved to the flattest areas with good traffic condition and water supplying. Besides, as climatic variations due to elevation differences between ridges and valley bottoms influence the land use types [7], vegetation construction would consider more about the suitability of plants, for example, forest in the Loess Plateau often moved to the valley with relative rich water now.

Therefore, analyzing the relationships between land use and topographic factors can reflect the effect of vegetation constructions and guide future vegetation restoration. However, this kind of this study is less common. The objectives of this study were to (i) detect the land use changes during 1986-2000 in the Jing River catchment on the Loess Plateau and to (ii) analyze the relationship between land use and topographic factors.

\section{Materials and methods}

\section{Study area}

The Jing River is a second order tributary of the Yellow river; the catchment is located in southern Loess Plateau of China (Figure 1). The catchment covers an area of $45,421 \mathrm{~km}^{2}$. The average annual precipitation in the catchment is $542.1 \mathrm{~mm}$ and the average annual temperature is $9.0{ }^{\circ} \mathrm{C}$. The southern part is more warm and wet than the northern part. The landscape is mainly forest-steppe ecotone. The soil is predominantly silt loam with silt content greater than $50 \%$. The population exceeds 6.2 millions. The elevation varies during 353$2761 \mathrm{~m}$. The erosion rate of the Jing River catchment is $5,015 \mathrm{t} \mathrm{km}^{-2} \mathrm{a}^{-1}$, and the area subject to water erosion is $33,220 \mathrm{~km}^{2}$, which accounts for $73 \%$ of the whole catchment [8].

\section{Data description}

Two land use maps of 1986 and 2000 (1:100,000), provided by the Environmental and Ecological Science Data Center for West China, were used to analyze the land use changes. The land use was classified into six categories: farmland, forest, grassland, water, construction land (areas for residence, traffic, industry and mining), and unused land.

Elevation and slope gradient was chosen as the indices of topography to study their relationship with land use. GDEM (Global Digital Elevation Model) of $30 \mathrm{~m}$, a product of Trade and Industry of Japan (METI) and the National Aeronautics and Space Administration (NASA), was used to provide the elevation. The elevation was classified into three categories: $<1000 \mathrm{~m}$ (mainly gully region), 1000-1500 m (mainly tableland region), and $>2000 \mathrm{~m}$ (mainly hilly region). A slope map was generated through DEM surface analysis operation of ArcGIS 9.2 and the slope gradient was classified into three categories: gentle $\left(<15^{\circ}\right)$, intermediate $\left(15-25^{\circ}\right)$, and steep $\left(>25^{\circ}\right)$ in accordance with the national policy on converting steep lands to other uses.

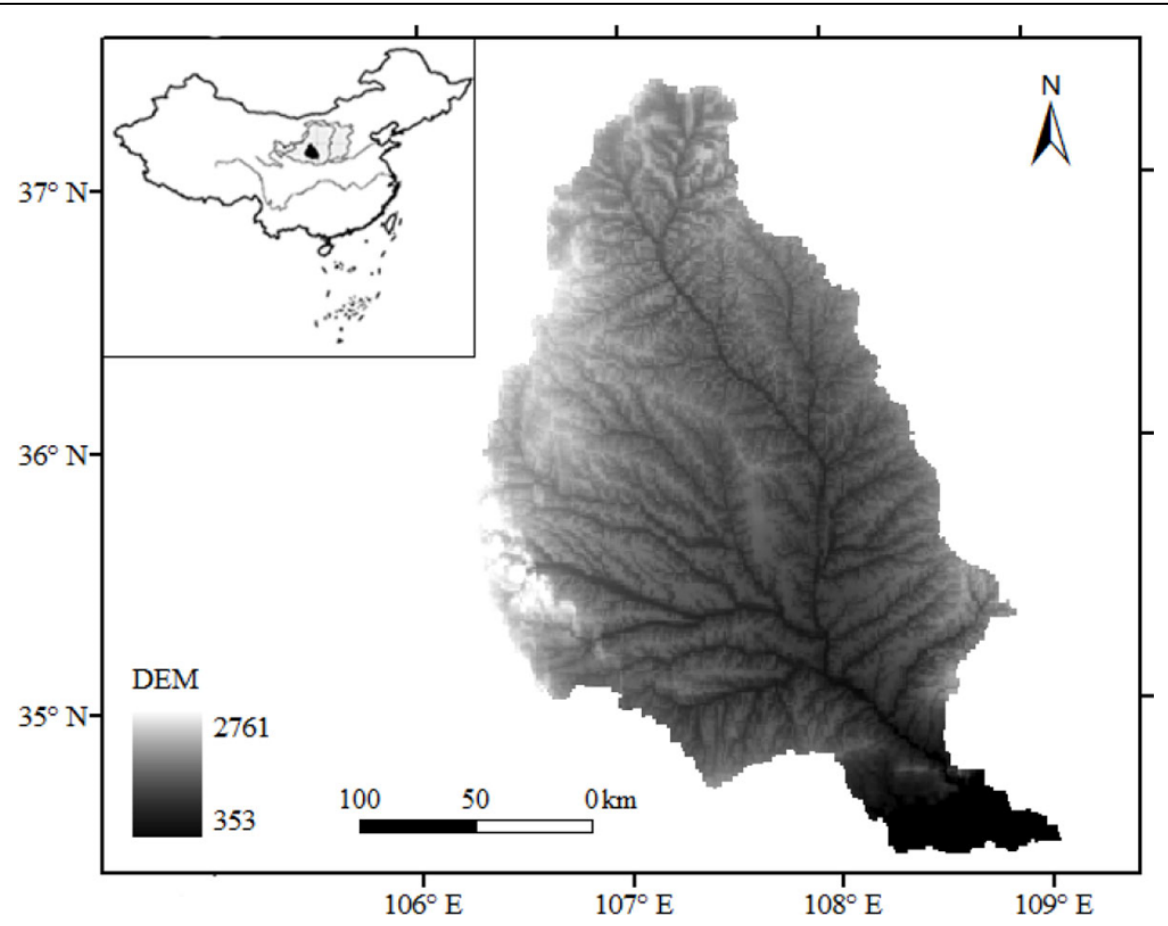

Figure 1 The location of the Jing River catchment. 


\section{Spatial analysis}

Spatial analysis was carried out by an overlaying operation of ArcGIS 9.2 to study the land use changes over time and to assess the relationship between land use and elevation or slope gradient. Through intersecting the two land use maps (1986 and 2000), a land use transformation map was extracted and used for subsequent transformation matrix analysis. Then several indices including change magnitude, speed and types were used to quantify land use changes. Change magnitude is the difference of area between the beginning and the end of the study period for each land use type. Change speed is usually quantified by the following equation:

$$
K_{i}=\frac{U_{b}-U_{a}}{U_{a}} \times \frac{1}{T} \times 100 \%
$$

where $K_{i}$ is the change speed for the $i$ th type land use; $U_{b}$ and $U_{a}$ is the area of a certain land use type at the beginning and end of the study period; $T$ is the time duration of the research. The change speed is thus defined as the change area per year, positive value refers to upward trend and negative value refers to downward trend.

To analyze the relationship between land use and topographic factors, the two land use maps were combined with DEM or slope gradient map through the grid extension of Arc/Info 9.2. All maps were grid format and the cell size was $30 \mathrm{~m} \times 30 \mathrm{~m}$. Through exporting the attribute table of the combined maps and calculating the elevation and slope gradient of different land use type in different year, the effects of biologic measures can be detected.

\section{Results and discussion}

\section{Changes in land use}

During 1986-2000, the dominant land use types in the Jing River catchment were farmland and grassland (Table 1), which accounted for about $88 \%$ of the entire area. Two main trends existed in land use changes, i.e. the decrease in farmland and forest, and the increase in grassland and construction land. Farmland and forest decreased by 85.1 and $123.8 \mathrm{~km}^{2}$, respectively; while grassland and construction land increased by 118.8 and $95.2 \mathrm{~km}^{2}$, respectively; water body and unused land decreased slightly. The changes in each land use type were the combined effects of two processes: conversion to other types and conversion from other types. For example, the area of grassland converted from other land use types $\left(202.9 \mathrm{~km}^{2}\right)$ was more than that of forest converted to other types $\left(184.6 \mathrm{~km}^{2}\right)$; however, the total change area of grassland $\left(118.8 \mathrm{~km}^{2}\right)$ was less than that of forest $\left(123.8 \mathrm{~km}^{2}\right)$ due to the balancing effect of the other process. In terms of change magnitude, land use was changing in the order of forest $>$ grassland $>$ construction land $>$ farmland $>$ water $>$ unused land. However, the change speed was in the order of unused land $>$ construction land $>$ forest $>$ water $>$ grassland $>$ farmland.

Table 2 lists the main types of land use changes. Overall, the land use in the Jing River catchment changed little from 1986 to 2000 , and only about $0.9 \%$ of the entire catchment has underwent type conversions. There were mainly six conversion types whose areas were more than $10 \mathrm{~km}^{2}$. The changes fell into three groups: (i) the mutual conversion between forest and grassland, (ii) the mutual conversion between farmland and grassland, and (iii) farmland converted to other land use types.

\section{Land use changes in relation to elevation}

The elevation distribution of each land use type is shown in Table 3. The elevation in the Jing River catchment was mostly over $1000 \mathrm{~m}$. The area with elevation during 1000-1500 m and over $1500 \mathrm{~m}$ accounted for $62 \%$ and $31 \%$ of the whole catchment, respectively. The mean elevation of each land use type was in the order of water and grassland (about $1100 \mathrm{~m}$ ) < construction land (about $1200 \mathrm{~m}$ ) < farmland (about $1310 \mathrm{~m}$ ) < forest and unused land (over $1500 \mathrm{~m}$ ). The elevation distribution of each land use type was different. About $60 \%$ of farmland, forest, grassland and construction land distributed within $1000-1500 \mathrm{~m}$, about $30 \%$ of farmland, forest and grassland distributed over $1500 \mathrm{~m}$; however, only

Table 1 Land use structure and their changes during 1986-2000 in the Jing River catchment

\begin{tabular}{|c|c|c|c|c|c|c|c|c|c|}
\hline \multirow[t]{2}{*}{ Land use } & \multicolumn{2}{|c|}{1986} & \multicolumn{2}{|c|}{2000} & \multirow{2}{*}{$\begin{array}{c}\text { Unchanged } \\
\text { area }\end{array}$} & \multirow{2}{*}{$\begin{array}{c}\begin{array}{c}\text { Changed } \\
\text { area }\end{array} \\
\left(\mathrm{km}^{2}\right)\end{array}$} & \multirow{2}{*}{$\begin{array}{c}\begin{array}{c}\text { Converted to } \\
\text { other types }\end{array} \\
\left(\mathrm{km}^{2}\right)\end{array}$} & \multirow{2}{*}{$\begin{array}{c}\begin{array}{c}\text { Converted from } \\
\text { other types }\end{array} \\
\left(\mathrm{km}^{2}\right)\end{array}$} & \multirow{2}{*}{$\begin{array}{c}\begin{array}{c}\text { Change } \\
\text { speed }\end{array} \\
(\%)\end{array}$} \\
\hline & $\left(\mathrm{km}^{2}\right)$ & $(\%)$ & $\left(\mathrm{km}^{2}\right)$ & $(\%)$ & & & & & \\
\hline Farmland & 20360.6 & 44.83 & 20275.5 & 44.64 & 20209.6 & -85.1 & 151.0 & 66.0 & -0.03 \\
\hline Forest & 4313.6 & 9.50 & 4189.8 & 9.22 & 4129.0 & -123.8 & 184.6 & 60.8 & -0.19 \\
\hline Grassland & 19843.8 & 43.69 & 19962.6 & 43.95 & 19759.7 & 118.8 & 84.1 & 202.9 & 0.04 \\
\hline Water & 205.1 & 0.45 & 201.3 & 0.44 & 199.7 & -3.8 & 5.4 & 1.6 & -0.12 \\
\hline Construction land & 695.4 & 1.53 & 790.6 & 1.74 & 695.4 & 95.2 & 0.0 & 95.2 & 0.91 \\
\hline Unused land & 2.4 & 0.01 & 1.0 & 0.002 & 1.0 & -1.4 & 1.4 & 0.0 & -3.84 \\
\hline
\end{tabular}


Table 2 Change types of land use during 1986-2000 in the Jing River catchment

\begin{tabular}{lccc}
\hline & Area $\left.\mathbf{( k m}^{\mathbf{2}}\right)$ & $\begin{array}{c}\text { Changes relative to } \\
\text { the entire area (\%) }\end{array}$ & $\begin{array}{c}\text { Changes relative to } \\
\text { each land use type (\%) }\end{array}$ \\
\hline Forest to grassland & 181.9 & 0.40 & 4.22 \\
Farmland to construction land & 92.6 & 0.20 & 0.45 \\
Grassland to farmland & 59.2 & 0.13 & 0.30 \\
Farmland to forest & 37.5 & 0.08 & 0.18 \\
Grassland to forest & 22.5 & 0.05 & 0.11 \\
Farmland to grassland & 20.1 & 0.04 & 0.10 \\
\hline
\end{tabular}

$10 \%$ of water and construction land located over $1500 \mathrm{~m}$ and over $20 \%$ of both types distributed below $1000 \mathrm{~m}$. The elevation distribution was related to the characteristics of each land use type. For example, as river run across hilly region with low elevation, construction land also located lowly due to the convenience of getting water for people.

In general, two trends existed in elevation changes of land use, i.e. the increase in elevation of farmland, forest, water and construction land, and the decrease in that of grassland and unused land. The changes in elevation for each land use type were significant. Specifically, land use changes mainly occurred during 1000$1500 \mathrm{~m}$. Farmland has substantially decreased by 113 $\mathrm{km}^{2}$ below $1500 \mathrm{~m}$ while increased by $27 \mathrm{~km}^{2}$ over 1500 $\mathrm{m}$, indicating that a large number of farmland in gully region was transferring to other land use types. Forest increased by $3 \mathrm{~km}^{2}$ below $1000 \mathrm{~m}$ and decreased by 128 $\mathrm{km}^{2}$ over $1000 \mathrm{~m}$, suggesting that forest were transferring to gully regions. Grassland and construction land increased despite the elevation. Grassland tended to increase in regions with high elevation while construction land increased preferably in tableland and rive valley with low elevation. The decrease in water mainly occurred over $1000 \mathrm{~m}$. The above changes in elevation of land use were possibly caused by the substantial conversion from forest to grassland, and conversion from farmland to construction land (Table 2).

\section{Land use changes in relation to slope gradient}

The mean slope gradient of each land use type was relatively small (Table 4) due to the predominant area of the tableland and river valley that were mostly flat. In general, the slope gradient of about $90 \%$ land was less than $15^{\circ}, 7 \%$ land was during $15^{\circ}-25^{\circ}$. The mean slope gradients of construction land, water and farmland were less than $10.7^{\circ}$, while those of forest, grassland and unused land were more than $13.5^{\circ}$. About $27 \%$ of farmland, $52 \%$ of forest, $43 \%$ of grassland, $12 \%$ percent of water and $9 \%$ of construction land distributed on areas with slope gradients over $15^{\circ}$. As $15^{\circ}$ was recommended by some experts as the critical degree to return farmland to other land use types, there are great potential of reducing farmland to promote ecologic environment.

During 1986-2000, the mean slope gradient of each land use type changed little except for the increase in unused land. The changes in land use mainly occurred at area with slope gradient less than $15^{\circ}$. Farmland decreased by $81 \mathrm{~km}^{2}$ with slope less than $15^{\circ}$ possibly because it was used as construction land (Table 2). Forest decreased while grassland increased despite slope gradient, which was possibly caused by the conversion

Table 3 Land use changes in relation to elevation during 1986-2000 in the Jing River catchment.

\begin{tabular}{|c|c|c|c|c|c|c|c|}
\hline & & Farmland & Forest & Grassland & Water & Construction land & Unused land \\
\hline \multirow[t]{3}{*}{ Mean elevation (m) } & 1986 & 1317 & 1520 & 1065 & 1104 & 1200 & 1544 \\
\hline & 2000 & 1314 & 1495 & 1098 & 1082 & 1175 & 1617 \\
\hline & Changes & 3 & 25 & -33 & 23 & 26 & -72 \\
\hline \multirow[t]{3}{*}{$1986\left(\mathrm{~km}^{2}\right)$} & $<1000$ & 1901 & 119 & 662 & 86 & 157 & 0 \\
\hline & $1000-1500$ & 12833 & 2645 & 12284 & 103 & 475 & 0 \\
\hline & $>1500$ & 5653 & 1518 & 6903 & 17 & 63 & 2 \\
\hline \multirow[t]{3}{*}{$2000\left(\mathrm{~km}^{2}\right)$} & $<1000$ & 1870 & 122 & 663 & 85 & 183 & 0 \\
\hline & $1000-1500$ & 12751 & 2569 & 12383 & 101 & 537 & 0 \\
\hline & $>1500$ & 5680 & 1466 & 6922 & 16 & 71 & 1 \\
\hline \multirow[t]{3}{*}{ Land use changes $\left(\mathrm{km}^{2}\right)$} & $<1000$ & -31 & 3 & 2 & 0 & 26 & 0 \\
\hline & $1000-1500$ & -82 & -76 & 99 & -2 & 61 & 0 \\
\hline & $>1500$ & 27 & -52 & 19 & -1 & 8 & -1 \\
\hline
\end{tabular}


Table 4 Land use changes in relation to slope during 1986-2000 in the Jing River catchment

\begin{tabular}{|c|c|c|c|c|c|c|c|}
\hline & & Farmland & Forest & Grassland & Water & Construction land & Unused land \\
\hline \multirow[t]{3}{*}{ Mean slope gradient $\left({ }^{\circ}\right)$} & 1986 & 10.71 & 16.68 & 14.78 & 6.35 & 5.62 & 13.54 \\
\hline & 2000 & 10.74 & 16.69 & 14.78 & 6.40 & 5.58 & 15.90 \\
\hline & Changes & 0.03 & 0.01 & 0.01 & 0.05 & -0.05 & 2.36 \\
\hline \multirow[t]{3}{*}{$1986\left(\mathrm{~km}^{2}\right)$} & $<15^{\circ}$ & 14974 & 2052 & 11233 & 180 & 633 & 1.5 \\
\hline & $15^{\circ}-25^{\circ}$ & 4316 & 1579 & 6602 & 18 & 50 & 0.7 \\
\hline & $>25^{\circ}$ & 1097 & 652 & 2013 & 7 & 13 & 0.1 \\
\hline \multirow[t]{3}{*}{$2000\left(\mathrm{~km}^{2}\right)$} & $<15^{\circ}$ & 14893 & 1986 & 11295 & 176 & 722 & 0.5 \\
\hline & $15^{\circ}-25^{\circ}$ & 4313 & 1529 & 6650 & 18 & 55 & 0.4 \\
\hline & $>25^{\circ}$ & 1095 & 643 & 2023 & 7 & 14 & 0.1 \\
\hline \multirow[t]{3}{*}{ Land use changes $\left(\mathrm{km}^{2}\right)$} & $<15^{\circ}$ & -81 & -66 & 62 & -4 & 89 & -1.1 \\
\hline & $15^{\circ}-25^{\circ}$ & -2 & -50 & 48 & 0 & 5 & -0.3 \\
\hline & $>25^{\circ}$ & -2 & -9 & 10 & 0 & 2 & 0 \\
\hline
\end{tabular}

from forest to grassland (Table 2). Unused land decreased in regions with small slope.

\section{Implication of land use changes and its relation to topographic factors}

The transferring direction of land use in the Jing River catchment during 1986-2000 can be detected according to the above results. Farmland has decreased greatly on tableland, which was possibly caused by converting farmland to construction land and increasing farmland by constructing terraces. Forest have moved to gully region with low elevation and small slope gradient, indicating that the vegetation construction of the Loess Plateau was getting more rational and considering more about the suitability of planting trees. Grassland has increased at all elevation and slope, implying that the effects of returning steep farmland to grassland and converting from forest to grassland were significant. Construction land has increased despite elevation and slope due to population increase. Unused land has moved to hilly region with high elevation and big slope gradient, suggesting the development and utilization of land use are more intensive.

Overall, the land use in the Jing River catchment during 1986-2000 was changing to a more reasonable spatial pattern, which considered more about the suitability of plants and human needs. This kind of changes will surely benefit the vegetation construction and sustainable development of this region.

\section{Conclusion}

The dominant land use types of the Jing River catchment were farmland and grassland. Overall, the land use changed little during 1986-2000, indicating that the soil conservations measures now implemented mainly focused on engineering measures, therefore, more attention should be paid to vegetation construction in the future. However, the land use distributions on elevation and slope gradients were becoming more reasonable, and the spatial pattern of land use were considering more about the suitability of plants and human needs. This kind of changes would indubitably promote the ecological environment and sustainable development of the region.

\section{Competing interests}

The authors declare that they have no competing interests.

\section{Acknowledgements}

This study was supported by the National Natural Science Foundation of China (41101022 and 51179161) and the Science and Technology Research and Development Program of Shaanxi Province, China (2013KJXX-18).

\section{Declarations}

The publication costs for this article were funded by Scientific \& Technical Development Inc.

This article has been published as part of SpringerPlus Volume 2 Supplement 1, 2013: Proceedings of the 2010 International Conference on Combating Land Degradation in Agricultural Areas (ICCLD'10). The full contents of the supplement are available online at http://www.springerplus.com/ supplements/2/S1.

\section{Authors' details}

${ }^{1}$ College of Natural Resources and Environment, Northwest A \& F University, Yangling Shaanxi, 712100 China. ${ }^{2}$ Institute of Soil and Water Conservation, CAS \& MWR, Yangling Shaanxi, China.

\section{Published: 11 December 2013}

\section{References}

1. $\mathrm{Xu}$ J: River sedimentation and channel adjustment of the lower Yellow River as influenced by low discharges and seasonal channel dry-ups. Geomorphology 2002, 43(1-2):151-164.

2. Zhang XC, Liu WZ: Simulating potential response of hydrology, soil erosion, and crop productivity to climate change in Changwu tableland region on the Loess Plateau of China. Agricultural and Forest Meteorology 2005, 131(3-4):127-142.

3. Li Z, et al: Impacts of land use change and climate variability on hydrology in an agricultural catchment on the Loess Plateau of China. Journal of hydrology 2009, 377(1-2):35-42.

4. Tang K, Zhang K, Lei A: Critical slope gradient for compulsory abandonment of farmland on the hilly Loess Plateau. Chinese Science Bulletin 1998, 43(5):409-412.

5. Chen $L$, et al: Land-use change in a small catchment of northern Loess Plateau, China. Agriculture, Ecosystems \& Environment 2001, 86(2):163-172. 
6. Fu B-J, et al: Temporal change in land use and its relationship to slope degree and soil type in a small catchment on the Loess Plateau of China. CATENA 2006, 65(1):41-48.

7. Shrestha DP, Zinck JA: Land use classification in mountainous areas: integration of image processing, digital elevation data and field knowledge (application to Nepal). International Journal of Applied Earth Observation and Geoinformation 2001, 3(1):78-85.

8. Ran DC, et al: Resear on effects of soil and water conservation measures on reduction of runoff and sediment in the typical catchments in the middle Yellow River. Zhengzhou: The Yellow River Water Conservancy Press; 2006.

doi:10.1186/2193-1801-2-S1-S3

Cite this article as: Li et al:: The land use changes and its relationship with topographic factors in the Jing river catchment on the Loess Plateau of China. SpringerPlus 2013 2(Suppl 1):S3.

\section{Submit your manuscript to a SpringerOpen ${ }^{\mathcal{O}}$ journal and benefit from:}

- Convenient online submission

- Rigorous peer review

- Immediate publication on acceptance

- Open access: articles freely available online

- High visibility within the field

- Retaining the copyright to your article

Submit your next manuscript at $\gg$ springeropen.com 